\title{
A Comparative Genre Analysis of Hedging Expressions in Research Articles: Is Fuzziness Forever Wicked?
}

\author{
Biook Behnam \\ Department of English, Tabriz Branch, Islamic Azad University, Tabriz, Iran \\ Amin Naeimi (Corresponding author) \\ Department of English, Yazd Branch, Islamic Azad University, Yazd, Iran \\ Tel: 98-913-354-3006Ｅ-mail: naeimiamin@gmail.com \\ Ali Darvishzade \\ Department of English, Payam-e Noor University, Yazd Branch, Yazd, Iran
}

Received: March 24, 2012

Accepted: April 25, 2012

Published: June 1, 2012

doi:10.5539/ells.v2n2p20

URL: http://dx.doi.org/10.5539/ells.v2n2p20

\begin{abstract}
Scientific writers might not inevitably be exact, precise and explicit in expression, eschewing vulnerability to criticism and seeking acceptability form academia. The present study aimed at investigating the frequency, form and function of the multi-objective linguistic and rhetorical device of hedging in the discussion sections of 100 qualitative and quantitative research articles where appropriate expression of scientific claims is highly welcome. As such, the taxonomy proposed by Hyland (1996) was applied in order to identify and classify the various hedge words, followed by an independent-samples t-test to compare the total number of hedging devices. The results revealed a statistically significant difference between qualitative and quantitative research articles with respect to both frequency and form of the employed hedge words, bearing important implications for educational researchers and practitioners in applying appropriate hedging strategies in the academic publishing of scientific texts.
\end{abstract}

Keywords: Hedging device, Qualitative research articles, Quantitative research articles, Frequency of hedge words, Form of hedge words, Function of hedge words

\section{Introduction}

Scientific writing has been inevitably associated with "exactness". The role of scientific writers, from many people's viewpoints, is to convey information in an explicit and precise way. However, a scientific writer has many reasons not to be exact and explicit; for example, he may consider the consequences of inadequacy in his scientific claim(s), or want to express his uncertainty about a scientific issue or reflect the state of knowledge. For Brown and Levinson (1988), presenting a scientific claim is a face threatening act, so even if the scientific writer is utterly certain about his claims to be presented explicitly and precisely with no anxiety for the later criticisms, some degree of uncertainty and fuzziness is often applied, to leave a little space for his readers. That is to say, it is not only the content that matters, but the way it is presented which is significant in the process of being accepted by a scientific community- a thing which is even evident, more or less, in every day acts of communication.

"Hedging" is a multi-objective linguistic device, the learning of which can help a researcher to appropriately express his scientific claims. There are different definitions for "hedging" and different authors have specified different taxonomies and functions for hedge words. For Salagar-Meyer (1994), investigating hedge words is not limited to scientific and academic writing (Adams-Smith, 1983, 1984; Kibui, 1988; McKinIay, 1983; Rounds, 1981, 1982; Prince et al., 1982 in; Pindi \& Bloor, 1986; Dubois, 1987; Myers, 1989). Others have gone far to investigate hedging in general language texts and contrastive rhetoric (Clyne, 1991; Markkanen \& Schroder, 1988 a,b; Powell, 1985; Skelton, 1988; Stubbs, 1986; Zuck \& Zuck, 1987).

Cherished by the similar purpose, the present study is a contrastive study of the frequency and function of hedge words in discussion sections of two important types of research articles namely qualitative and quantitative. As such, the taxonomy proposed by Hyland (1996) was applied in order to identify and classify the various hedge words, 
followed by an independent-samples t-test to compare the total number of hedging devices. There are two reasons for putting emphasis on research articles in this study. The first reason is that majority of research article writers use hedge words in different sections of their articles for different purposes (Hyland, 1996 a,b; Salagar-Meyer, 1994; Smith, 1984; Varttala, 2001). The second reason is the importance of research articles in academic discourse (Holmes, 1988; Hyland, 1996; Myers, 1989; Salagar-Meyer et.al, 1998; Samroj, 2002; Vancle, Kopple \& Crismor, 1990; Varttala, 2001, Vassilva, 2001; Yang, 2003). As such, the following research questions were posed:

1. What are the frequency and form of the hedge words used in discussion section of quantitative research articles?

2. What are the frequency and form of the hedge words used in discussion section of qualitative research articles?

3. Is there a significant difference between qualitative and quantitative research articles considering the frequency and form of hedge words used in their discussion section?

\section{Function of Hedge Words}

Generally speaking, one can not find a consensus among researchers about the functions that are fulfilled by hedge words. Robert Boyle (1965) suggested that hedge words could be used to convey personal modesty and humility. Perhaps the most famous pioneer in the study of hedging is Lakoff (1973), who defined hedging devices as "words or phrases whose job is to make things more or less fuzzy" (p. 471). Lakoff, along with other researchers such as Hyland (1996), Myers (1985) and Salagar-Meyer (1994), is the most prominent figure who investigated "hedging" from different points of view, for example hedging in different genres, the effect of culture on using hedge words, the possibility of teaching students to use hedge words, etc. According to Lakoff (1973), sometimes a sentence can be neither true, nor false, nor nonsense. That is to say "natural languages have vague boundaries and fuzzy edges" (Lakoff 1973, p. 458). Lakoff $(1973,1975)$ considered two main functions for hedge words. The first one was to show the lack of certainty on the part of author and the second one was to mitigate the author's claim for the purpose of politeness. Zadeh (1965) used "fuzzy set theory" to say it is not the case that an individual is always a member of a group or never a member of a group; instead, he can be a member of any group to some extent. Dubois (1987) believed that hedging is used to express the author's claim in an unobtrusive way, an idea which is shared by many other researchers such as Prince, Frader and Bosk (1982), Round (1982), Pindi and Bloor (1982) and Skelton (1988). According to Powell (1987) as hedges reflect the writer's or speaker's judgment, they have an "evaluative" function. As Crystal (1987) put it, using hedge words are not always rooted in the author's lack of knowledge. He brought forward three other reasons for using hedge words:

1. People intentionally do not like to be precise all the time.

2. Sometimes, specifically in scientific writings, the writer understands that the audience needs only "half truth".

3. Using hedge words can act as safe guard, impeding further questions.

Hyland (1994) summarized the functions of hedge words and considered two main roles for them:

1. Expressing claims with certain degree of caution, modesty and humility.

2. Diplomatic negotiation of the claim when referring to work of collogues and competitors.

Further, he believed that when an author wants to develop his hypothesis into knowledge, he needs to achieve acceptance from the audience. For this to happen, he needs "linguistic and rhetorical means of persuasion" (Hyland, 1994, p. 435) and this may the basis for the use of hedge words.

Salagar-Meyer (1994) specified two main purposes for using hedge words. The first one is to make the issue fuzzy. She proposed that explicit expression of a claim makes it easy for others to criticize the author's claim and reflects his lack of humility, and his ignorance of the others in that research area. The other purpose is to increase the precision in the author's claim. That is to say, as Salagar-Meyer (1994) put it, "hedging may present ... the strongest claim a careful researcher can make" (p. 151). Hedging can reflect the state of knowledge under discussion too. There are other researchers who considered this latter role for hedging (Round, 1981; Tarontino, 1991; Skelton, 1988; Gilbert \& Mulkay, 1984). Crompton (1997) provided a definition for hedge words in which the main function is to "explicitly qualify author's lack of knowledge to the truth of the proposition he utters" (p. 273). Clemen (1997) said that the way we can achieve hedging is through setting utterances in context rather than straight forward statement.

Varttola (1999) investigated the issue from another point of view. To him, the communicative functions of hedges are different in specialist research articles and popular research articles. He maintained that in popular research article, hedging indicates "textual precision and interpersonal negative politeness" (p. 177), and in specialist research articles it functions as "textual tools for both imprecision and precision and a feature of interpersonal 
positive politeness" (p. 177). Specialist articles refer to those articles that are written by a specialist for other specialists, whereas popular articles refer to those articles that are written by a specialist to non-specialist readers. Myers (1985) had the same idea. He considered hedging as part of a politeness system whose job is to reduce the threat contained in the author's claim to the face of the readers. Hyland (1996) considered hedging as playing the central role in gaining ratification from a powerful peer group. Other commentators underscored the role of the audience in the process of hedging. Horn (2001) believed that transfer from one type of publication to another might have some effects on hedges. Fahnestock (1996) believed that when we publish information from a scientific article in a popular press, most of the time we omit hedge words. In contrast Fornsworth (1990) believed that when a scientific article is converted for extended audience, hedge words should not be omitted.

Isabel (2001) believed that hedging is important for two main reasons. The first is to show the author's attitude toward his claim and the second reason is to show the author's attitude toward the readers, i.e., the author presents his claim based on his expectations from the readers. Horn (2001) asserted that for science to progress, the author has to gain acceptance from audience for the added information. By accepting he does not mean full agreements with the conclusion but a tentative agreement by the scientific community. One way to achieve this consensus is through the citation of the past research. Horn (2001) believed that "keeping, dropping or changing the hedges will affect the consensus building that a writer is trying to develop" (p. 1088). Marco and Mercer (2004) held that citation creates textual means to relate different articles from a research community. They pointed out that hedging is used not only to enhance or mitigate the authors' claim but also to help the author simultaneously express his claim, question current beliefs and maintain his position in the community. They concluded that citation often happens in sentences marked by hedging cues. Lewin (2005) suggested five main functions for hedging in scientific articles: politeness, self protection, politics (the need to appear modest), evading responsibility and conceal the truth. But contrary to many others such as Myers (1989) or Martin-Martin (2008), the results of Lewin's investigation show that authors of different articles do not consider "politeness" as the main reason for using hedge words.

As Banzermen (2003) put it, using hedge words by an author depends on some factors such as what the author is going to express? Who is going to be persuaded by what is claimed by the author? What are usually the audience reactions to new claims? And finally what is the main purpose of that scientific branch? Persuasion thus is one of the effects of using hedge words. Some researchers suggested that using hedge words reduces the persuasion power of the text (Carli, 1990; Gibsons, Buch \& Baradak, 1991; Holtgraves \& Lasky, 1999; Hosmon, 1989; Hosmon, Hubner \& Siltamen, 2002). Some other researchers indicated that using hedge words leads to negative perception of the source and a weaker evaluation of the argument (Blankenship \& Holtgraves, 2005; Hosmon \& Siltamen, 2006). Durik et al. (2008) believed that if the writer presents the hedge words in the statement containing data (not interpretation of data), it would lead to "negative perception of the source policy and argument" (p. 230). They pointed out that if we divide the hedge words into colloquial (those usually not presented in the research articles such as "sort of") and professional or academic (those usually presented in the research articles such as "possibly"), the presence of colloquial hedges in interpreting statements causes negative evaluation.

Vass (2004) argued that there is a direct relationship between hedging and prototypical features of different genres. After analyzing hedging in two legal written discourse genres, namely U.S. Supreme Court opinions and American Law Review articles, he concluded that hedging is a genre specific subject matter. He considered three different aspects in order to define hedging which are semantic and pragmatic, social and cognitive (i.e. a proposition is hedged when the writer produces the hedge word and it is interpreted by the reader).

Cabanes (2007) specified three main rhetorical functions or communicative goals for hedging in research articles which include showing politeness as well as difference toward audience, self protection from consequences of inappropriate claims and considering some degrees of precision. Duenas (2007) considered "impersonalization" or paling the role of author as the main function of using hedge words. He believed that this is the reason why we can find a plethora of passive voices or nominalizations in research articles. Based on Duenas, "self-mention" and "reference to author" are also rhetorical devices that are mostly used by authors to present themselves as "authorial". Martin-Martin (2008) supported Myers (1989) that "scientific discourse consists of interaction among scientists in which maintenance of face is crucial", and considered "politeness" as the main function fulfilled by hedge words. The other function of hedging based on Martin-Martin is to avoid categorical expressions.

\section{Distribution of Hedges in Research Articles}

Although hedge words are used more in spoken language (Stubbs, 1986; Coats, 1987), most research has so far focused on written works. Considering only written language, Hyland (1996) argues that the distribution of hedges across various sections of research articles reflects their essentially rhetorical role in discourse. There may be different ways to divide a research article into different sections. But the most prevalent way to introduce an 
organization for research articles can be to divide them into "introduction, method, results and discussion". This organization has been applied by different researchers to approach distribution of hedge words (Lau, 1999; Swales, 1990). Lau (1999) analyzed 100 articles in Taiwanese. His study was on text structures of different sections in scientific research articles. The results from his study suggest that hedges are mostly used in discussion sections because "writers are dealing with logical reasoning when they present experimental results in discussion section" (p. 433). The reason why they are not used frequently in method section is that "the truth is simply reported rather than commented" in this section (p. 433). The same results were achieved in a more recent work by Durik et al. (2008). They tested the effects of hedge placement and hedge type on attitudes, source evaluation and perception of argument strength. The results from this study show that discussion sections of research articles are the most heavily hedged sections. Durik et al. (2008) believe that this is because hedges are used when the author wants to interpret the data. Salagar-Meyer (1994) also achieved the same results that hedge words are used more frequently in discussion section because "it is in this section of research papers that writers speculate, argue, contrast and extrapolate from the described results, and at the same time avoid stating results too conclusively so that the reader can note that the authors are not claiming to have the final word on the subject" (p. 163). Kelly and Banzermen (2003) presented a pattern for distribution of hedge words in this way: high, low and high. It means that in the first part (mostly introduction) hedge words are used frequently, in the second part (mostly method) hedge words are used less frequently, and finally in the third part (mostly result and discussion) again they are used more frequently. Similar results were obtained by Skelton (1988) who divided science articles into beginning, middle and end (except for humanity articles). He analyzed 20 articles from hard sciences. In this study, texts were examined for expressions such as "it cannot be denied, it seems likely, it was presumed," and the following results were achieved; \%19.3 end section, \%9.70 beginning section and \%4.39 middle section. That is, comments are most frequent in end sections, less in beginning sections and finally least in middle sections. It is worth mentioning that Skelton's proposed organization of research articles (beginning, middle and end) is interpreted as introduction, method and results and discussion by some researchers such as Durik et al. (2008).

\section{Cross-linguistic Studies on Hedging}

There are many factors influencing the way an author uses hedge words. The amount of hedging, to a great extent, depends on the audience or the readers whom the author wants to address. Some writers do not hedge risky information (Simpson, 1990), and there is a relatively fixed pattern for the distribution of hedge words in research articles. Another important factor is the field that the author represents. For example, as Spillner (1983, p. 35) put it "in texts in which the use of experimental data and logical deduction are not so important, the style of writing becomes an essential element in achieving credibility. The degree to which the author is successful to convince his reader in such texts depends upon the way he uses linguistic devices including hedging" (p. 35).

Different studies, taking into consideration authors or texts from different languages, indicated that most of the time the language one speaks or writes, affects the frequency and function of hedge words (Connor, 1995; Setter, 1998). In the same line, Bloor and Bloor (1991) believed that "there are clearly identifiable differences in degrees of directness and concessions permitted (or encouraged) in academic writing in different languages" (p. 1). As mentioned by Hyland (1994), academic writing in German and Czech appear to be more direct than in English, while Finns (Mauranen, 1993), Japanese (Harder, 1994), Malays (Ahmad, 1995) and Chinese (Bloch and Chi, 1995) seem to favor an indirect style when expressing opinions. English and German are compared in a study by Clyne (1991), who investigated the form of hedge words and their frequency. In addition to the similarities across these two languages, the results reveal a more frequent presence of hedge words in the texts written by German writers. The results also indicate that using double and triple hedging is the norm in German but not in English.

English and Bulgarian were compared in a study by Vassileva (2001). She emphasized on three types of texts, namely texts written by English authors, texts written by Bulgarian authors and texts written by Bulgarian authors in English. The results of her study revealed that hedge words were most prevalent in texts written by English authors and least frequent in English texts written by Bulgarian authors with Bulgarian texts standing in between.

Yang (2003) compared English and Chinese in material sciences. Despite some similarities, he concluded that Chinese writers tend to be more direct and authorative in tone as a result of higher frequency of approximators and lower frequency of plausibility shields. Winardi (2008) also compared English (English written by American authors) and Chinese. He focused on texts written by linguists. His study indicated the difference between Chinese and English authors considering the form and frequency of hedge words; American authors used more adjective, adverbial, nominal phrases and introductory phrases than Chinese authors. On the other hand, Chinese authors used modal lexical verbs and approximators more than English authors did.

Tatis and Rowland (2006) compared Greek and English in mathematical discourse. In their study, the emphasis was 
on "participant face work". The authors suggested that although in both languages authors try to preserve their hearer face and use vague language to do so, the Greek author "may choose to threaten his/her partners' face in order to maintain his/her own face" (p. 257).

English and Spanish articles were compared in a study by Duenas (2007), who suggested that self-mention is different in these two languages considering both frequency and function. Another comparison between Spanish and English was done in a study by Martin-Martin (2008). This study investigated the genre of clinical health and psychology, putting emphasis on the strategies of hedging and their frequency. He concluded that although these two languages have many points in common in this respect, one can find "more protection to author face" in English articles (p. 133).

Falahati (1994) compared English and Persian, scrutinizing 12 research articles in each language. The findings of his study showed that research articles written in English were 61.3\% more hedged than Persian research articles. Atai and Sadr (2004) selected 108 applied linguistic articles written by English and Persian native speakers. The authors investigated the difference between these two languages focusing on the strategies of using hedge words. The study led to the conclusion that Persian native speakers use limited number of forms to express tentativeness and a degree of commitment to the truth value of their claims.

\section{Qualitative and Quantitative Research Articles: Definitions and Differences}

Many researchers focused their studies on these two research genres especially over the past two decades (Ary, et al., 1996; Jacob, 1987; Larsen-Freeman \& Long, 1991; Seliger \& shohamy, 1989; Tashakkori \& Teddlie, 1998; to mention only a few). Quantitative research is defined by Brown and Rodgers (2002) as "investigative procedures used to describe in numerical terms a setting and the things going on in it" (p. 279). For them, quantitative research includes exploratory research (examining correlation among variables), quasi-experimental (comparing group behavior using intact groups) and experimental research (comparing group behavior using random assignments to groups).

For Mackey and Gass (2005), in quantitative research "variables are manipulated to test hypothesizes" (p. 396) and researchers usually use quantification of data and numerical analysis. As Mackey and Gass put it, there are two types of quantitative research, namely associational and experimental. In the former, the researcher tries to determine if there is a relationship between two variables and if such relationship exists, recognize the strength of it. In an experimental research, however, the researcher tries to see if manipulation of one variable (usually called treatment) has some effects on other variables or not. As Mason (1996) pointed out, one cannot find a unified set of techniques or philosophies that are represented by qualitative research. Based on Mason, qualitative research "has grown out of a wide range of intellectual and disciplinary traditions" (p. 3). Aryadoust (2007) believed that qualitative research comes from the discipline of anthropology and sociology and deals with studying the natural occurring human behavior in context. In this research genre, the researcher tries not to affect the "normal behavior of the subjects" (p. 195). For Strauss and Corbin (1990) qualitative research is "any kind of research that produces finding not arrived at by means of statistical procedures or other means of quantification" (p. 17). Merriam (1988) provided the a table in order to make a systematic distinction between qualitative and quantitative research genres (see Table 1). However, it is not always so simple to divide research articles into qualitative and quantitative, a thing which is referred to as "oversimplification" by Grotjahn (1987). That is to say, the line between these two research genres is a fuzzy one. The reason is that sometimes qualitative research uses numbers and there are some quantitative researches that are not based on numerical data (Brown \& Rodgers, 2002).

\section{Method}

In order to identify hedge words in the selected articles, the taxonomy suggested by Hyland (1996) was used. There are two main reasons for using this taxonomy over other proposed ones. The first reason is that contrary to many taxonomies presented for hedge words, Hyland's emphasis is on the function of hedge words rather than their parts of speech. The second reason is that his taxonomy is more organized and easy to detect, which makes it more practical than other taxonomies. Here, we need to divide statements into factive and non-factive. Factive statements need no hedging. The hedge words used in non-factive statements are divided into content-oriented and reader-oriented. Content-oriented hedge words are, by themselves, divided into accuracy-oriented and writer-oriented, and finally accuracy-oriented hedge words are divided into attribute and reliability (see Figure 1):

1. Content-Oriented hedges: The role of content-oriented hedges is to mitigate the author's claim. That is to say they "hedge the correspondence between what the writer says about the world and what the world is thought to be like" (Hyland, 1996, p. 439) 
(1.1). Accuracy-Oriented: Authors, most of the time, want to be as precise as possible so sometimes, because of personal or general lack of knowledge, they have to use some forms that reflect this imprecision. (So we can say something between $55 \%$ and $60 \%$ of the times the material can be recovered).

(1.1.1). Attribute hedges: Hedge words indicate that what is presented as the author's claim is not necessarily the exact way nature behaves, so as Hyland mentioned they "allow a better match with familiar descriptive terms" (p. 441).

(1.1.2). Reliability hedges: Hedge words are used to express author's tentativeness and include modal auxiliaries, full verbs, modal verbs, modal adverbs, adjectives and nouns. Hyland believed that they express the present states and are present in active not passive voice. (What I suggest is that by means of this new mechanism we can increase our production).

(1.2). Writer-Oriented hedges: Hedge words reflect the author's attempt to diminish his own role in order to be protected from consequences of being wrong. Using impersonal constructions and passive voice are some means to do that. (So it can be assumed that our methodology can not work in this condition; The findings show the imprecise nature of our approach).

2. Reader-Oriented hedges: Generally speaking, hedge words show the author's respect to his audience as intelligent members of a scientific community and presents his view in such a way that they feel they have some space for their own judgment. Hyland (1996) considers this category as very important especially for non-native speakers if they want to achieve acceptance in academic world.

It is also important to note that "particular linguistic forms can not automatically be associated with specific interpretation, but one and the same form may be seen to involve various functions. Consequently, a certain degree of indeterminacy of the functions of hedging is to be irresistible and it is viewed as a multi function phenomenon" (Hyland, 1998, p. 77). In other words, hedging devices have different semantic interpretations as well as a range of meanings for particular users in particular context.

Hyland (1996) suggests the following tentative generalizations in determining the core cases:

1. Where the principal role of the hedging device is to specify the extent to which a term accurately describes the reported phenomena, it is likely to be acting as an attribute hedge.

2. Where the principal role of the hedging device is to convey the writer's assessment of the certainty of the truth of a proposition, then it is likely to be performing a reliability function.

3. Where the device occurs in a context which conceals the writer's viewpoint and avoids personal responsibility for propositional truth, then it is probably acting as a writer-oriented hedge.

4. Where the writer acknowledges personal responsibility for the validity of propositional content or invites reader involvement, then the device is likely to be acting as a reader-oriented hedge.

\subsection{The Corpus}

A total number of 100 (50 qualitative and 50 quantitative) research articles from some leading journals in the field of applied linguistics namely, ELT, IRAL, Applied Linguistics, SLR, Second Language Studies, TESOL Quarterly, SSLA were analyzed. The first step to do was to select articles which conformed to the characteristics of qualitative and quantitative research genres. Perry's (2005) explanation about the distinction between qualitative and quantitative research articles was used to distinguish between these two research types. He believes that there are two main differences in this regard:

1. Quantitative research articles come mainly from the field of psychology in which the emphasis is on the use of statistics but qualitative research articles come mainly from the fields of anthropology and sociology and rely heavily on verbal description rather than numbers.

2. Quantitative research articles use sample strategies for generalizing findings to larger populations but qualitative research articles work to uncover information from information-rich samples.

In sum, articles with social content are mainly qualitative and experimental articles are mainly quantitative. Quantitative articles deal with numbers to represent their data, but this role, in qualitative articles, is mostly played by verbal description, and finally, qualitative articles are more subjective than quantitative ones.

Following Perry (2005), the qualitative research articles were chosen from descriptive and heuristic sociolinguistics and discourse analysis articles, while quantitative ones were selected from those articles which had used experimentation in their methodologies. In addition, the selected corpus was examined by an inter-rater to obtain more reliability for the study and the Phi coefficient value of .96 was achieved, indicating a high inter-rater 
reliability ensuring agreement between the raters. The discussion section of the selected articles were analyzed because, as it was mentioned before, many studies show that it is in this section that the highest frequency of hedge words occurs (Durik et al., 2008; Lau, 1999; Salagar-Meyer, 1994; Skelton, 1998, to name only a few). As mentioned by Hyland (1998) "The level of generality and therefore the density of hedges is much here [discussion section], as writers explore the ratification of their results" (p. 154).

\section{Results}

The discussion section of the selected articles in both research genres was analyzed and the hedging devices were identified. The data was also analyzed by an expert of the field for recognition of hedge words and a Phi coefficient of .94 was achieved that indicated a high inter-rater reliability. In order to see if there was a significant difference between qualitative and quantitative genres with respect to total number of hedging devices and the number of hedging devices in each subcategories, namely reliability, attribute, writer-oriented and reader-oriented, the data were analyzed by means of independent-samples t-test with alpha value set up at .05 .

Regarding the frequency and form of hedges used in the discussion section of the quantitative genre, the results show that a total of 1932 hedging devices were used by the authors including 1081 reliability, 325 attribute, 448 writer-oriented and 78 reader-oriented. Table 2 shows the summary of results achieved for quantitative research genre.

Regarding the frequency and form of hedges used in the discussion section of the qualitative genre, the results show that a total of 2769 hedging devices were used by the authors including 1499 reliability, 479 attribute, 627 writer-oriented and 164 reader-oriented. Table 3 shows the summary of results achieved for qualitative research genre.

An independent-samples t-test was conducted to compare the total number of hedging devices in the discussion section of qualitative and quantitative research articles. There was a significant difference in the total number of hedges for quantitative $(\mathrm{M}=38.64, \mathrm{SD}=23.53)$ and qualitative $(\mathrm{M}=55.38, \mathrm{SD}=17.27)$ research genres, with $\mathrm{t}(98)=-4.055, \mathrm{p}=.000$ (see Tables 4 and 5). The results suggest that the discussion sections of qualitative research articles are more hedged than discussion sections of quantitative research articles. Figure 2 shows schematically that qualitative research articles are more abundant with hedges than quantitative ones.

An independent-samples t-test was conducted to compare the number of hedges under the category of "reliability" in the discussion section of qualitative and quantitative research articles. There was a significant difference in the number of reliability hedges for quantitative $(M=21.62, S D=15.97)$ and qualitative $(M=29.98, S D=9.60)$ research genre; $\mathrm{t}(98)=-3.171, \mathrm{p}=.002$ (see Tables 6 and 7). Reliability hedges are shown to be used significantly more in the discussion sections of qualitative research articles than those of quantitative research. Figure 3 shows schematically that qualitative research articles are more abundant with reliability hedges than quantitative ones.

An independent-samples t-test was conducted to compare the number of hedges under the category of "attribute" in the discussion section of qualitative and quantitative research articles. There was a significant difference in the number of attribute hedges for quantitative $(\mathrm{M}=6.5, \mathrm{SD}=5.95)$ and qualitative $(\mathrm{M}=9.58, \mathrm{SD}=3.84)$ research genre; $t(98)=-3.070, p=.003$ (see Tables 8 and 9). The results suggest that attribute hedges are used significantly more in the discussion sections of qualitative research articles than the discussion sections of quantitative research articles. Figure 4 shows schematically that qualitative research articles are more abundant with attribute hedges than quantitative ones.

An independent-samples t-test was conducted to compare the number of hedges under the category of "writer-oriented" in the discussion section of qualitative and quantitative research articles. There was a significant difference in the number of writer-oriented hedges for quantitative $(\mathrm{M}=8.96, \mathrm{SD}=6.16)$ and qualitative $(\mathrm{M}=12.54$, $\mathrm{SD}=4.56$ ) research genre; $\mathrm{t}(98)=-3.302, \mathrm{p}=.001$ (see Tables 10 and 11). The results reveal that writer-oriented hedges are used significantly more in the discussion sections of qualitative research articles than those of quantitative research articles. Figure 5 shows schematically that qualitative research articles are more abundant with writer-oriented hedges than quantitative ones.

An independent-samples t-test was conducted to compare the number of hedges under the category of "reader-oriented" in the discussion section of qualitative and quantitative research articles. Again, there was a significant difference in the number of reader-oriented hedges for quantitative $(\mathrm{M}=1.56, \mathrm{SD}=2.20)$ and qualitative $(\mathrm{M}=3.28, \mathrm{SD}=2.01)$ research genre; $\mathrm{t}(98)=-4.075, \mathrm{p}=.000$ (see Tables 12 and 13). The results suggest that reader-oriented hedges are used significantly more in the discussion sections of qualitative research articles as compared to quantitative research articles. Figure 6 shows schematically that qualitative research articles are more abundant with reader-oriented hedges than quantitative ones. Considering the results mentioned above, a significant 
difference has been achieved in all the independent samples t-test analyzing the differences between quantitative and qualitative research type in terms of the frequency and form of hedge words.

\section{Discussion}

Hedging is a rhetorical device that reflects the author's concerns about what happens to his claims in the future considering both the content and its acceptance by the scientific community. Being fully accurate and explicit not only makes the author vulnerable to criticism, but also acts as a face threatening act to other members of the scientific community. Hedging has been the focus of many researchers' attention since Lakoff (1973). Researchers such as Hyland and Milton (1997), Hyland (2000), Wishnoff (2000) and Isabel (2001) believe that it is important to know how to use hedge words for L2 learners because it directly influences getting acceptance by international scientific journals which are "English only" based on Belcher (2007). According to Hyland (1996), hedges are "among the primary features which shape the research articles as the principal vehicle for new knowledge" (p.452). Hedging is therefore a considerable resource in academic writing whose occurrence is to a large extent dependent on the discourse genre in question. According to many genre analysis studies of hedge words, we can consider "hedging" as a genre specific rhetorical strategy. The genre specific nature of hedging is evident in the studies that investigated the distribution of hedge words in research articles. The results from studies such as the ones by Skelton (1988), Lau (1999), Salagar-Meyer (1994), Kelly and Banzermen (2003) and Durik et al. (2008) suggest that authors tend to use hedge words more frequently in the discussion section of their research articles.

Based on the results achieved from the present study, discussion sections of qualitative articles are more heavily hedged than discussion sections of quantitative articles. That is to say, considering both the total number of hedging devices and each subcategory, i.e., reliability, attribute, writer-oriented and reader-oriented, hedging devices are used more frequently in the discussion sections of qualitative articles than those of quantitative articles. Many reasons can be brought forward to justify the more frequent occurrence of hedging devices in qualitative research genre. This is discussed here with respect to discipline, data, sample size and role of the researcher.

1. Discipline: Qualitative and quantitative research genres come from different disciplines (Perry, 2005). Qualitative research deals mostly with sociolinguistics and discourse analysis, and the focus is on the social behavior of human being. As far as human being and his condition is always subject to change and generally speaking, human social behavior is to a large extent unpredictable, then authors in qualitative research genre need to be more cautious. That is to say, in qualitative research genre, it is more difficult to make a claim or generalization than in quantitative research genre, and that is why in qualitative research genre authors are more scrupulous and use hedging devices more frequently. The results from the present study support Vass (2004) claim about hedges being genre specific. He believes that any two genres can be different in terms of the prototypical features of the genres such as contextual and communicative ones.

2. Data: In quantitative research genre the emphasis is on statistics to make generalization, but in qualitative research genre the emphasis is on verbal description. Interpretation of numerical data is both easy and limited, yet it is not the case for verbal data. There might be a plethora of explanations for even a single sentence. Generally speaking, the author is more confident when he discusses the results achieved from numerical data than when he discusses the results achieved from verbal description. It is clear that whenever the author is less confident, he uses more hedging device to express this uncertainty and lack of precision.

3. Sample Size: In qualitative research genre the emphasis is on attitudes, behavior and experiences, and therefore the number of participants or the research sample size cannot be very large because of the data collection method that the authors are supposed to apply. In quantitative research genre, however, researchers can have a large number of participants; data collection methods, such as using questionnaires, help researchers have many participants in their studies. Apparently, when a researcher has only a few participants in his study, he needs to be more cautious about the claims he makes based on the results achieved from his investigation, hence a more frequent use of hedging devices.

4. Role of the Researcher: Qualitative research is more subjective than quantitative research. What is claimed in qualitative research is, to a large extent, influenced by the researcher's own interpretation and inclination. This can also be seen in the data collection process, for example, when the way the researcher asks his questions in the interview, may influence the way participants answer the questions. In quantitative research, however, the author tries to stand out of the research. Therefore, the researcher's personal involvement in qualitative research genre is greatly absent in quantitative research genre, the author in qualitative research genre being more responsible for what is presented and consequently more open to questions. Hedging devices are therefore used more frequently by authors in qualitative research genre in order to protect themselves from later criticisms. 


\section{Conclusion}

The vague expression of claims or low coloring of the presence of the author in the text has many advantages for the authors of scientific articles considering later criticisms or inaccuracy of their scientific claims. Using a hedge word means that either the author is not certain about what he says - that may be rooted in his lack of knowledge or general lack of knowledge in one specific subject matter - or he wants to present his claim in such a way that it does not seem offensive for the rest of the scientific community. Although every one agrees that "hedging" is the part and parcel of academic writing, there is no consensus among scholars about its functions, this being reflected in different definitions and taxonomies presented for hedging.

Cross-linguistic studies indicate that differences between languages with regard to using hedge words are- most of the time -significant. Therefore, it is very important for those who want to present their articles in popular scientific journals to be able to use hedge words appropriately. Fortunately, results from different studies show that "hedging" is teachable. These studies also suggest different ways to teach students how to use hedge words. According to Markannen and Schroder (1997), as far as rules of appropriateness are different in different cultures, if a writer wants to be an effective communicator in a foreign language, he needs to acquire these rules. They believed that knowing such rules is part of the author's pragmatic competence, "lack of which may lead to foreign language use to mistakes that are more serious than, for example, grammatical errors" (p. 13). Hyland (1996) investigated the ways hedge words can be taught and the factors that may impede second language learners to use hedge words appropriately. As he put it, presenting students with high frequency hedging devices in authentic texts would develop students' competence in this regard. After analyzing some articles written in English and Cantonese, Hyland and Milton (1997) suggested that non-native speakers are not successful in expressing precise degree of certainty and most of the time they convey strong claims. Hyland (2000) asserted that students do not pay much attention to hedges and reading a hedged text is not different from reading a text without hedge words, considering students' learning of the texts. But the results from Crismore and Vande Kopple (1997 a,b) showed that the reverse is true. They gave a hedged text to one group of students and the same text without the hedge words to another group. The results indicated that the first group (those who read hedged text) learned more and developed a more positive attitude toward the text. Wishnoff (2000) investigated whether it is possible to teach pragmatic devices (including hedging) through instruction. She concluded that the significant difference between the performance of the control and treatment group proves the possibility of teaching students to use hedge words through instruction. Isabel (2001), like Hyland (2000), believed that second language learners pay scant attention to hedge words. She suggested that through consciousness raising activities, it is possible to increase students' level of attention to hedge words, leading to their better understanding of academic texts. Lin and Liou (2006) analyzed 20 articles from applied linguistic journals. They characterized communicative moves that are used to express different written purposes and genre linguistic conventions on hedging devices. They suggested a web-based material to teach students how to use hedge words.

Studies of genre analysis of hedging are not at the incipient stages, but there still remain many issues to be investigated, for example, regarding the effect of instructional intervention, norms of appropriateness, attitude and cultural background. It is hoped that the work reported in the present study will inspire other researchers to further explore such issues of importance.

\section{References}

Adams-Smith, D. E. (1983). Prescribing and general practice: Styles in medical journals. Paper presented at TESOL Convention.

Ahmad, U. K. (1995). Academic language and culture: Some observations on scientific Malay and scientific English. Paper presented at RELC Conference. Singapore.

Ary, D., Jacobs, L. C., \& Razavieh, A. (1996). Introduction to research in education (5th ed.). Fort Worth, TX: Harcourt Brace.

Aryadoust, S. V. (2007). A dictionary of sociolinguistics plus pragmatics and linguistics. Faramatn Publication.

Bahita, V. (2008). Genre analysis and professional practice. English for Specific Purposes, 27, 161-174. http://dx.doi.org/10.1016/j.esp.2007.07.005

Banzerman, C. (1981). What written knowledge does: Three examples of academic discourse. Philosophy of social the Social Sciences, 11(3), 361-88.

Banzerman, C. (1988). Shaping written knowledge: The genre and activity of experimental article in science. Madison, W: University of Wisconsin Press. 
Banzermen, C., \& Kelly, G. (2003). How students argue scientific claims. Applied Linguistics, 24(1), 28-55. http://dx.doi.org/10.1093/applin/24.1.28

Bardovi-Harling, K., \& Hartford, B. S. (1993). Learning the rules of academic talk. Studies in Second Language Acquisition, 15, 279-304. http://dx.doi.org/10.1017/S0272263100012122

Berkenkotter, C., \& Huckin, T. (1995). Genre knowledge in disciplinary communication: cognition/culture/power. Hillsdale, NJ: Erlbaum.

Bijker, W., Hughes, T., \& Pinch, T. (1987). The social construction of technological systems. Cambridge, M.A: MIT. Blakeslee, A. (2001). Interacting with audiences. Mahwah NJ: Erlbaum.

Blankenship, K. L., \& Holtgraves, T. (2005). The role of different markers of linguistic powerlessness in persuasion. Journal of Language and Social Psychology, 24, 3-24. http://dx.doi.org/10.1177/0261927X04273034

Bloch, J., \& Chi, L. (1995). A comparison of the use of citations in Chinese and English academic discourse. In D. Belcher, \& G. Braine (Eds.), Academic writing in a second language: Essays on research and pedagogy (pp. X-274). Norwood NJ: Ablex.

Bloor, M., \& Bloor, T. (1991). Cultural expectation and socio-pragmatic failure in academic writing. In B. Adams, B. heston, \& P. Howarth (Eds.), Socio-cultural issues in English for academic purposes, 1-12. Review of ELT 1.

Brown, J. D., \& Rodgers, T. S. (2002). Doing second language research. Oxford University Press.

Brown, P., \& Levinson, S. (1988). Politeness: Some universals in language usage. Cambridge University Press.

Burrough-Boenisch, J. (2005). NS and NNS scientists' amendments of Dutch scientific English and their impact on hedging. English for Specific Purposes, 24, 25-39. http://dx.doi.org/10.1016/j.esp.2003.09.004

Cabanes, P. P. (2007). A contrastive analysis of hedging in English and Spanish architecture projects descriptions. RESLA, 20, 139-158.

Canagarajah, S. (2000). Understanding L2 academic writing as code switching. Paper presented in the Thirty-forth Annual Convention of TESOL, 14-18 March.

Carli, L. L. (1990). Gender, language and influence. Journal of Personality and Social Psychology, 59, 941-951. http://dx.doi.org/10.1037/0022-3514.59.5.941

Clemen, G. (1997). The concept of hedging: Origins, approaches and definitions. In R. Markkanen, \& H. Schroder (Eds.), Hedging and discourse: Approaches to the analysis of a pragmatic phenomenon in academic texts. New York:Walter de Gruyter.

Clyne, M. (1987). Cultural differences in organization of academic texts: English and German Journal of Pragmatics, 11, 211-241.

Clyne, M. (1991). The sociocultural dimension: The dilemma of the German speaking scholar. In H. Schroder (Ed.), Subject-oriented texts: Languages for special purposes and text theory (pp. 49-68). Berlin: de Gruyter.

Coats, J. (1987). Epistemic modality and spoken discourse. Transactions of the Philological Society, 85, 100-131.

Connor, U. (1987). Argumentative patterns in student essays: Cross cultural differences. In U. Connor, \& R. Kaplan (Eds.), Writing across languages: Analysis of L2 text (pp. 57-71). Reading, MA: Addison Wesley.

Connor, U. (1995). Contrastive rhetoric: Cross-cultural aspects of second language writing. Cambridge: Cambridge University Press.

Crismore, A., \& Farnsworth, R. (1990). Metadiscourse in popular and professional science discourse. In W. Nash (Ed.), The Writing Scholar (pp.118-136). Newbury Park (CA): Sage Publications.

Crismore, A., \& Vande Kopple, W. J. (1997a). The effects of hedges and gender on the attitudes of readers in the United States toward material in a science textbook. In A. Dusak (Ed.), Culture and styles of academic discourse (pp. 223-247). Berlin: Mouton de Gruyter. http://dx.doi.org/10.1515/9783110821048.223

Crismore, A., \& Vande Kopple, W. J. (1997b). Hedges and readers: Effects on attitudes and learning. In R. Markkanen, \& H. Schroder (Eds.), Hedging and discourse: Approaches to the analysis of a pragmatic phenomenon in academic texts. (pp. 83-114). Berlin: Walter de Gruyter.

Crystal, D. (1988). On keeping one's hedges in order. English Today, 4(3), 46-47. http://dx.doi.org/10.1017/S0266078400003540

Dubois, B. L. (1986). From New England Journal of Medicine and JAMA through the Association Press to the local 
news paper scientific translation for the laity. In T. Bungarten (Ed.), Wissenschaftssprachen und Gesellschaft: A spekte der Kommunikation un des Wissenschafers in der heutigen zeit (pp. 243-253). Hamburg: Akademion.

Dubois, B. L. (1987). Something on the order of around forty to forty four: Imprecise numerical expressions in biomedical slide talks. Language and Society, 16, 527-541. http://dx.doi.org/10.1017/S0047404500000361

Duenas, P. M. (2007). 'I/we focus on...': A cross-cultural analysis of self-mentions in business management research articles. English for Academic Purposes, 6, 143-162. http://dx.doi.org/10.1016/j.jeap.2007.05.002

Durik, A., Britt, A., Reynolds, R., \& Story, J. (2008). The effects of hedges in persuasive arguments: A nuanced analysis of language. Journal of Language and Social Psychology, 27, 217-234. http://dx.doi.org/10.1177/0261927X08317947

Fahnestock, J. (1986). Accommodating science: The rhetorical life of scientific facts. Written Communication, 3(3), 275-9. http://dx.doi.org/10.1177/0741088386003003001

Falahati, R. (2004). A contrastive study of hedging in English and Farsi academic discourse. M.A thesis. Tehran University, Tehran, Iran.

Gibsons, P., Buch, J., \& Baradak, J. J. (1991). Powerful versus powerless language: consequences for persuasion, impression formation and cognitive response. Journal of Language and Social Psychology, 10, 115-133. http://dx.doi.org/10.1177/0261927X91102003

Gilbert, G. N., \& Muikay, M. (1984). Opening the Pandoras Box: A sociological analysis of scientific discourse. Cambridge, UK: Cambridge University Press.

Gross, A. (1990). The Rhetoric of science. Cambridge, M.A: Harvard University Press.

Grotjahn, R. (1987). On the methodological basis of introspective methods. In C. Farch, \& G. Kasper (Eds.), Introspection in second language research (pp. 54-81). Clevedon, UK: Multilingual Matters.

Harder, B. (1984). Cultural attitudes in discourse analysis. Canadian Journal of Linguistics, 29, 115-130.

Holmes, J. (1988). Doubt and certainty in ESL textbooks. Applied Linguistics, 9, 21-44. http://dx.doi.org/10.1093/applin/9.1.21

Holtgraves, T. M., \& Lasky, B. (1999). Linguistic power and persuasion. Journal of Language and Social Psychology, 17, 506-516.

Horn, K. (2001). The Consequences of citing hedged statements in scientific research articles. Journal of Bio Science, 51, 1086-1093. http://dx.doi.org/10.1641/0006-3568(2001)051[1086:TCOCHS]2.0.CO;2

Hosmon, L. A. (1989). The evaluative consequences of hedges, hesitation, and intensifiers: powerful and powerless speech styles. Human Communication Research, 15, 383-486. http://dx.doi.org/10.1111/j.1468-2958.1989.tb00190.x

Hosmon, L. A., Huebner, T. M., \& Siltamen, S. A. (2002). The impact of power of speech style, argument strength, and need for cognition in impression formation, and persuasion. Journal of Language and Social Psychology, 21, 361-379. http://dx.doi.org/10.1177/026192702237954

Hosmon, L. A., \& Siltamen, S. A. (2006). Powerful and powerless language forms: their consequences for impression formation, attribution of control of self, cognitive responses and message memory. Journal of Language and Social Psychology, 25, 33-34. http://dx.doi.org/10.1177/0261927X05284477

House, J., \& Kasper, G. (1981). Politeness markers in English and German. In F. Coulmas (Ed.), Conversational Routine: Exploration in Standardized Communication Situations and Prepatterned Speech. The Hague: Moutton.

Hyland, K. (1994). Hedging in academic writing and EAP textbooks. English for Specific Purposes, 13, 239-256. http://dx.doi.org/10.1016/0889-4906(94)90004-3

Hyland, K. (1996). Writing without conviction: Hedging in scientific research articles. Applied Linguistics, 17, 433-454.

Hyland, K. (1998a). Hedging in scientific research articles. Amsterdam: John Benjamins.

Hyland, K. (1998b). Boosting, hedging and the negotiation of academic knowledge. Text, 18, 349-382. http://dx.doi.org/10.1515/text.1.1998.18.3.349

Hyland, K. (2000). Hedges, boosters and lexical invisibility. Language Awareness, 9, 179-197. http://dx.doi.org/10.1080/09658410008667145

Hyland, K., \& Milton, J. (1997). Qualification and certainty in students writing. Journal of Second Language Writing, 6, 183-205. http://dx.doi.org/10.1016/S1060-3743(97)90033-3 
Isabel, M. (2001). Teaching academic reading: Some initial findings from a session on hedging. Proceedings of the Postgraduate Conference 2001 - Department of Theoretical and Applied Linguistics, The University of Edinburgh.

Jacob, E. (1987). Qualitative research traditions: a review. Review of Educational Research, 57(1), 1-50. http://dx.doi.org/10.2307/1170355

Kibui, A. (1988). Aspects of hedging in discussion of medical research discourse (LSU ESP Collection). MSc in TESP Dissertation. University of Aston in Birmingham.

Knotter-Cetia, K. (1999). Epistemic cultures: How the sciences make knowledge. Cambridge, M.A: Harvard University Press.

Lakoff, G. (1972). Hedges: A study in meaning criteria and the logic of fuzzy concepts. Journal of Philosophical Logic, 2, 458-508.

Lakoff, R. (1973). Language and woman's place. Language in Society, 2, 45-79. http://dx.doi.org/10.1017/S0047404500000051

Lakoff, R. (1975 ). Language and Woman's Place. Harper \& Row, New York.

Larsen-Freeman, D., \& Long, M. (1991). An introduction to second language acquisition research. New York, NY: Longman Inc.

Lau, H. H. (1999). Hedging expressions as signals of evidence in academic journal discourse. Selected papers from the $8^{\text {th }}$ int'l symposium on English teaching (pp. 431-440). Taipei: Crane.

Lewin, B. A. (2005). Hedging: an exploratory study of authors' and readers' identification of 'toning down' in scientific texts. English for Academic Purposes, 4, 163-178. http://dx.doi.org/10.1016/j.jeap.2004.08.001

Lin, M. C., \& Liou, H. C. (2006). Development of online materials for academic English writing: Contribution of text analysis on the discussion section of research articles. Paper presented at the 23rd International Conference on English Teaching and Learning in the Republic of China (ROC-TEFL). May 27-28. English Department, Wenzao Ursuline College of Languages, Kaohsiung.

Mackey, A., \& Gass, S. M. (2005). Second language research: Methodology and design. Mahwah, NJ: Lawrence Elbaum Association.

Marco, C., \& Mercer, R. (2004). Hedging in scientific articles as a means of classifying citations. Madison, W: University of Wisconsin Press.

Markkanen, R., \& Schroder, H. (1997). Hedging and discourse: Approaches to the analysis of a pragmatic phenomenon in academic texts. Berlin: Walter de Gruyter.

Martin-Martin, P. (2008). The mitigation of scientific claims in research papers: A comparative study. International Journal of English Studies, 8, 133-152.

Mason, J. (1996). Qualitative research. London: Sage.

Mauranen, A. (1993). Contrastive ESP rhetoric: Metatext in Finnish-English Economics texts. English for Specific Purposes, 12, 3-22. http://dx.doi.org/10.1016/0889-4906(93)90024-I

McKinIay, J. (1983). An analysis of the discussion sections of medical journal articles. Unpublished MA dissertation, University of Birmingham.

Merriam, S. (1988). Case study research in education: A qualitative approach. San Francisco: Jossey-Bass.

Myers, G. (1985). Texts as knowledge claims: The social constructions of two biology articles. Social Studies of Science, 15, 593-630. http://dx.doi.org/10.1177/030631285015004002

Myers, G. (1989). The pragmatics of politeness in scientific articles. Applied Linguistics, 10, 1-35. http://dx.doi.org/10.1093/applin/10.1.1

Perry, F. L. (2005). Research in applied linguistics: becoming a discerning consumer. Lawrence Erlbaum Associates.

Petric, B. (2005). Contrastive rhetoric in the writing classroom: a case study. English for Specific Purposes, 24, 213-228. http://dx.doi.org/10.1016/j.esp.2004.09.001

Pindi, M., \& Bloor, T. (1986). Playing safe with predictions: Hedging, attribution and conditions in economic forecasting. Written Language. BAAL 2. CILT.

Pinch, T. (1986). Confronting nature. Dordrench: R. Reidel. 
Powell, M. J. (1985). Purposive vagueness: An evaluation dimension of vague quantifying expressions. Journal of Linguistics, 21, 31-50. http://dx.doi.org/10.1017/S002222670001001X

Prince, E. F., Frader, R. J., \& Bosk, C. (1982). On hedging in physician-physician discourse. In J. di Prieto (Ed.), Linguistics and the Professions (pp. 83-97). Nor-wood, NJ: Ablex Publishing Corporation.

Rounds, P. (1981). On hedging in social science written texts. University of Michigan: Mimeo.

Rounds, P. (1982). Hedging in written academic discourse: Precision and flexibility. University of Michigan: Mimeo.

Salagar-Meyer, F. (1994). Hedges and textual communicative function in medical English written discourse. English for Specific Purposes, 13, 149-170. http://dx.doi.org/10.1016/0889-4906(94)90013-2

Salagar-Meyer, F. (1998). Research and discourse note: language is not a physical object. English for Specific Purposes, 17, 271-287.

Salager-Meyer, F., Defives, G., Jensen, C., \& De Filips, M. (1989). Principal component analysis and medical English discourse: An investigation into genre analysis. System, 17, 21-34. http://dx.doi.org/10.1016/0346-251X(89)90057-2

Simpson, M. J. (2000). Total structure analysis of academic paragraphs in English and Spanish. Second Language Writing, 9, 293-309. http://dx.doi.org/10.1016/S1060-3743(00)00029-1

Samraj, B. (2002). Introductions in research articles: variation across disciplines. English for Specific Purposes, 21, 1-17. http://dx.doi.org/10.1016/S0889-4906(00)00023-5

Seliger, H. W., \& Shohamy, E. (1989). What is research: A paradigm for second language research. Second Language research Methods, 1-41. Oxford, UK: Oxford University Press.

Skelton, J. (1988). Care and maintenance of hedges. ELT Journal, 42, 37-43.

Smith, E. E., \& Osherson, D. N. (1984). Conceptual combination with prototype concepts. Cognitive Science, 8 , 357-361. http://dx.doi.org/10.1207/s15516709cog0804_2

Spillner, B. (1983). Methodische aufgaben der fachsprachenforschung und ihre konsequenzenfuden fremdsprachenunterricht. In H. P. Kelz (Ed.), Fachsprache 1: Sprachanalyse und Vermittlungsmethoden. Bonn.

Strauss, A., \& Corbin, J. (1990). Basics of qualitative research: Grounded theory procedures and techniques. Newbury Park, CA: Sage Publications, Inc.

Stubbs, M. (1986). A matter of prolonged fieldwork: Notes towards a model grammar of English. Applied Linguistics, 7, 1-25. http://dx.doi.org/10.1093/applin/7.1.1

Swales, J. (1981). Aspects of article introductions. Birmingham, UK: The University of Aston in Birmangham.

Swales, J. (1998). Other Floors, other voices. Mahwah, NJ: Erlbaum.

Tarantino, M. (1991a). Scientific English: Qualitative factors via modern rhetoric. UNESCO-ALSED LSP Newsletter, 13(3), 51-60.

Tarantino, M. (1991b). EST: Dispassionate discourse and the discreet presence. UNESCO-ALSED-LSP Newsletter, 13(4), 28-34.

Tashakkori, A., \& Teddlie, C. (2003). Handbook of Mixed Methods in Social and Behavioral Research. Thousand Oaks CA: Sage.

Tatis, K., \& Rowland, T. (2006). Vague language in Greek and English mathematical talk: A variation study in face-work. Conference of the International Group for the Psychology of Mathematics Education, 5, 257-264. Prague: PME.

Van Nostrand, A. D. (1997). Fundamental knowledge: The marketing of defense technology. Mahwah, NJ: Erlbaum.

Varttala, T. A. (1999). Remarks on the communicative function of hedging in popular scientific and specialist research articles in medicine. English for Specific Purposes, 18, 177-200. http://dx.doi.org/10.1016/S0889-4906(98)00007-6

Varttala, T. A. (2001). Hedging in scientifically oriented discourse: Exploring variation according to discipline and intended audience. Unpublished $\mathrm{PhD}$ dissertation. University of Tarnpereen Yliopisto, Finland. [Online] Available: http://acta.uta.fi//pdf/95 1-44-5 195-3.

Vass, H. (2004). Socio-cognitive aspects of hedging in two legal discourse genres. IBÉRICA, 7, 125-141. 
Vassileva, I. (2001). Commitment and detachment in English and Bulgarian academic writing. English for Specific Purposes, 20(1), 83-102. http://dx.doi.org/10.1016/S0889-4906(99)00029-0

Vold, E. (2006). Epistemic modality markers in research articles: a cross-linguistic and cross-cultural study. International Journal of Applied Linguistics, 17(1).

Winardi, A. (2008). The use of hedging devices by American and Chinese writers in the field of applied linguistics. Jurnal Sastra Inggris, 8(3), 9285-9312.

Winzor, D. A. (1996). Writing like an engineer: A rhetorical Education. Mahwah, NJ: Lawrence Elbaum Association.

Wishnof, J. R. (2000). Hedging your bets: L2 learners` acquisition of pragmatic devices in academic writing and computer-mediated discourse. Second Language Studies, 19, 119-148.

Yang, Y. (2003). A contrastive study of hedges in English and Chinese academic discourse. Unpublished MA thesis. Jilin University, Changchun, China.

Zadeh, L. (1965). Fuzzy Sets. Information and Control, 8, 338-53. http://dx.doi.org/10.1016/S0019-9958(65)90241-X

Zuck, J. G., \& Zuck, L. V. (1987). Hedging in news writing. In A. M. Comu, J. Vanparijs, \& M. De Naye (Eds.), Beads or bracelets: How do we approach LSP? (pp. 172-181). Leuven, Belgium: Oxford University Press.

Table 1. Distinctive characteristics of qualitative and quantitative research. Adopted from Merriam, S. (1988)

\begin{tabular}{|lll|}
\hline \multicolumn{1}{|c|}{ Point of Comparisons } & Qualitative Research & Quantitative Research \\
\hline Focus of research & Quality (nature, essence) & Quantity (how much, how many) \\
\hline Philosophical roots & Phenomenology, symbolic interaction & Positivism, logical empiricism \\
\hline Associated phrases & $\begin{array}{l}\text { Fieldwork, ethnographic, naturalistic, } \\
\text { grounded, subjective }\end{array}$ & Experimental, empirical, statistical \\
\hline Goal of investigation & $\begin{array}{l}\text { Understanding, description, } \\
\text { discovery, hypothesis generating }\end{array}$ & $\begin{array}{l}\text { Prediction, control, description, } \\
\text { confirmation, hypothesis testing }\end{array}$ \\
\hline Design characteristics & Flexible, evolving, emergent & Predetermined, structured \\
\hline Setting & Natural, familiar & Unfamiliar, artificial \\
\hline Sample & Small, non-random, theoretical & Large, random, representative \\
\hline Data collection & $\begin{array}{l}\text { Researcher as primary instrument, } \\
\text { interviews, observations }\end{array}$ & $\begin{array}{l}\text { Inanimate instruments (scales, tests, } \\
\text { surveys, questionnaires, computers) }\end{array}$ \\
\hline Findings & $\begin{array}{l}\text { Inductive (by researcher) } \\
\text { Comprehensive, holistic, expansive }\end{array}$ & $\begin{array}{l}\text { Precise, narrow, reductionist } \\
\text { Deductive (by statistical methods) }\end{array}$ \\
\hline
\end{tabular}

Table 2. Summary of the quantitative genre analysis

\begin{tabular}{|c|c|c|c|c|c|}
\hline & $\begin{array}{c}\text { Total Number of } \\
\text { Hedging Devices }\end{array}$ & Reliability & Attribute & Writer Oriented & Reader Oriented \\
\hline $\begin{array}{c}\text { Quantitative } \\
\text { Genre }\end{array}$ & 1932 & 1081 & 325 & 448 & 78 \\
\hline
\end{tabular}


Table 3. Summary of the qualitative genre analysis

\begin{tabular}{|c|c|c|c|c|c|}
\hline & $\begin{array}{c}\text { Total Number of } \\
\text { Hedging Devices }\end{array}$ & Reliability & Attribute & Writer Oriented & Reader Oriented \\
\hline $\begin{array}{c}\text { Qualitative } \\
\text { Genre }\end{array}$ & 2769 & 1499 & 479 & 627 & 164 \\
\hline
\end{tabular}

Table 4. Mean number of hedge words used in quantitative and qualitative articles

\begin{tabular}{|c|c|c|c|c|c|}
\hline & & & & & Std. Error \\
& Article Genre & N & Mean & Std. Deviation & Mean \\
\hline Total Number of Hedges & Quantitative & 50 & 38.6400 & 23.53006 & 3.32765 \\
& Qualitative & 50 & 55.3800 & 17.27791 & 2.44347 \\
\hline
\end{tabular}

Table 5. Independent samples t-test analysis of hedge words used in quantitative and qualitative articles

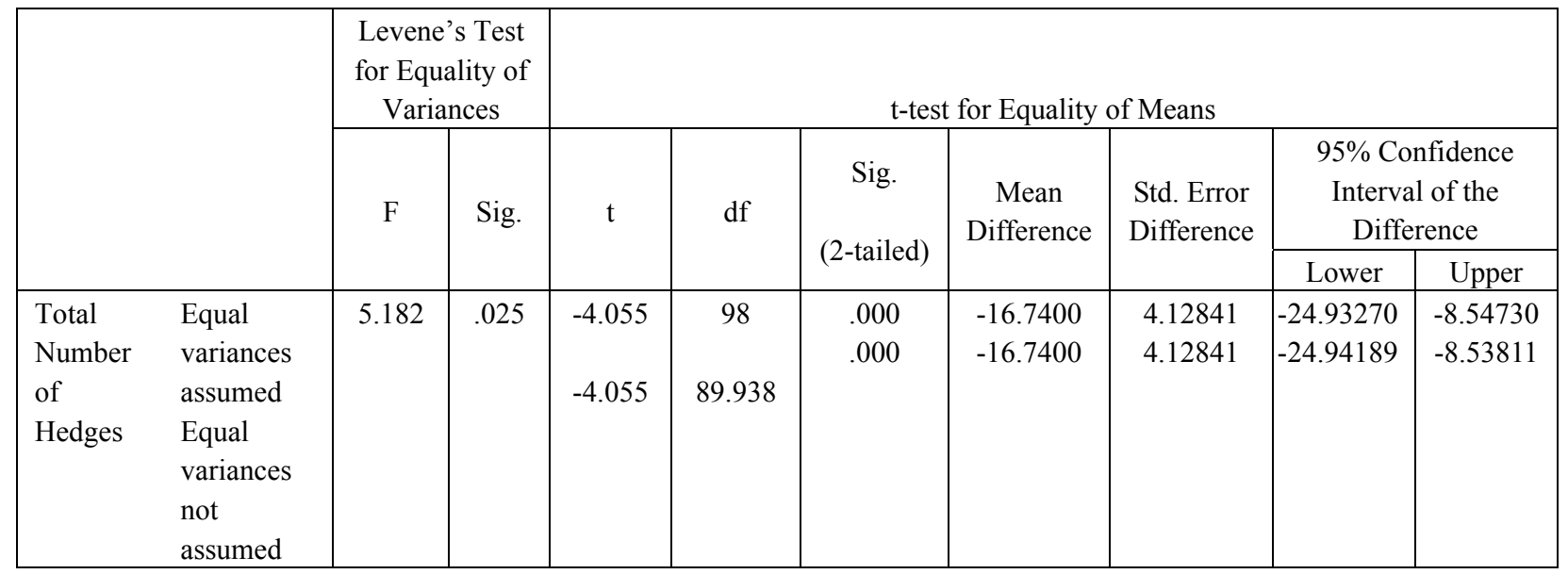

Table 6. Mean number of "reliability" hedges in quantitative and qualitative articles

\begin{tabular}{|cc|c|c|c|c|}
\hline & Article Genre & N & Mean & Std. Deviation & $\begin{array}{c}\text { Std. Error } \\
\text { Mean }\end{array}$ \\
\hline Reliability & Quantitative & 50 & 21.6200 & 15.97816 & 2.25965 \\
& Qualitative & 50 & 29.9800 & 9.60759 & 1.35872 \\
\hline
\end{tabular}

Table 7. Independent samples t-test analysis of "reliability" hedges used in quantitative and qualitative articles

\begin{tabular}{|c|c|c|c|c|c|c|c|c|c|c|}
\hline & \multicolumn{2}{|c|}{$\begin{array}{c}\text { Levene's Test } \\
\text { for Equality of } \\
\text { Variances } \\
\end{array}$} & \multicolumn{7}{|c|}{ t-test for Equality of Means } \\
\hline & & \multirow[t]{2}{*}{$\mathrm{F}$} & \multirow[t]{2}{*}{ Sig. } & \multirow[t]{2}{*}{$\mathrm{t}$} & \multirow[t]{2}{*}{ df } & \multirow[t]{2}{*}{$\begin{array}{c}\text { Sig. } \\
\text { (2-tailed) }\end{array}$} & \multirow[t]{2}{*}{$\begin{array}{c}\text { Mean } \\
\text { Difference }\end{array}$} & \multirow[t]{2}{*}{$\begin{array}{l}\text { Std. Error } \\
\text { Difference }\end{array}$} & \multicolumn{2}{|c|}{$\begin{array}{c}95 \% \text { Confidence } \\
\text { Interval of the } \\
\text { Difference }\end{array}$} \\
\hline & & & & & & & & & Lower & Upper \\
\hline Reliability & $\begin{array}{l}\text { Equal } \\
\text { variances } \\
\text { assumed } \\
\text { Equal } \\
\text { variances } \\
\text { not } \\
\text { assumed }\end{array}$ & 11.315 & .001 & $\begin{array}{l}-3.171 \\
-3.171\end{array}$ & $\begin{array}{c}98 \\
80.336\end{array}$ & $\begin{array}{l}.002 \\
.002\end{array}$ & $\begin{array}{l}-8.3600 \\
-8.3600\end{array}$ & $\begin{array}{l}2.63669 \\
2.63669\end{array}$ & $\begin{array}{l}-13.59243 \\
-13.60685\end{array}$ & $\begin{array}{l}-3.12757 \\
-3.11315\end{array}$ \\
\hline
\end{tabular}


Table 8. Mean number of "attribute" hedges in quantitative and qualitative articles

\begin{tabular}{|c|c|c|c|c|c|}
\hline \multicolumn{2}{|c|}{ Article Genre } & $\mathrm{N}$ & Mean & Std. Deviation & $\begin{array}{c}\text { Std. Error } \\
\text { Mean }\end{array}$ \\
\hline \multirow{2}{*}{ Attribute } & Quantitative & 50 & 6.5000 & 5.95990 & .84286 .54 \\
& Qualitative & 50 & 9.5800 & 3.84968 & 443 \\
\hline
\end{tabular}

Table 9. Independent samples t-test analysis of "attribute" hedges used in quantitative and qualitative articles

\begin{tabular}{|c|c|c|c|c|c|c|c|c|c|c|}
\hline & \multicolumn{2}{|c|}{$\begin{array}{c}\text { Levene's Test } \\
\text { for Equality of } \\
\text { Variances } \\
\end{array}$} & \multicolumn{7}{|c|}{ t-test for Equality of Means } \\
\hline & & \multirow[t]{2}{*}{$\mathrm{F}$} & \multirow[t]{2}{*}{ Sig. } & \multirow[t]{2}{*}{$\mathrm{t}$} & \multirow[t]{2}{*}{ df } & \multirow[t]{2}{*}{$\begin{array}{c}\text { Sig. } \\
\text { (2-tailed) }\end{array}$} & \multirow[t]{2}{*}{$\begin{array}{c}\text { Mean } \\
\text { Difference }\end{array}$} & \multirow[t]{2}{*}{$\begin{array}{l}\text { Std. Error } \\
\text { Difference }\end{array}$} & \multicolumn{2}{|c|}{$\begin{array}{l}95 \% \text { Confidence } \\
\text { Interval of the } \\
\text { Difference }\end{array}$} \\
\hline & & & & & & & & & Lower & Upper \\
\hline Attribute & $\begin{array}{l}\text { Equal } \\
\text { variances } \\
\text { assumed } \\
\text { Equal } \\
\text { variances } \\
\text { not } \\
\text { assumed }\end{array}$ & 7.331 & .008 & $\begin{array}{l}-3.070 \\
-3.070\end{array}$ & $\begin{array}{c}98 \\
83.826\end{array}$ & $\begin{array}{l}.003 \\
.003\end{array}$ & $\begin{array}{l}-3.0800 \\
-3.0800\end{array}$ & $\begin{array}{l}1.00340 \\
1.00340\end{array}$ & $\begin{array}{l}-5.07121 \\
-5.07543\end{array}$ & $\begin{array}{l}-1.08879 \\
-1.08457\end{array}$ \\
\hline
\end{tabular}

Table 10. Mean number of "writer-oriented" hedges in quantitative and qualitative articles

\begin{tabular}{|l|c|c|c|c|c|}
\hline \multirow{4}{*}{ Writer-Oriented } & & & & & Std. Error \\
& Article Genre & $\mathrm{N}$ & Mean & Std. Deviation & Mean \\
\cline { 2 - 6 } & Quantitative & 50 & 8.9600 & 6.16097 & .87129 .64 \\
& Qualitative & 50 & 12.5400 & 4.56343 & 537 \\
\hline
\end{tabular}

Table 11. Independent samples t-test analysis of "writer-oriented" hedges used in quantitative and qualitative articles

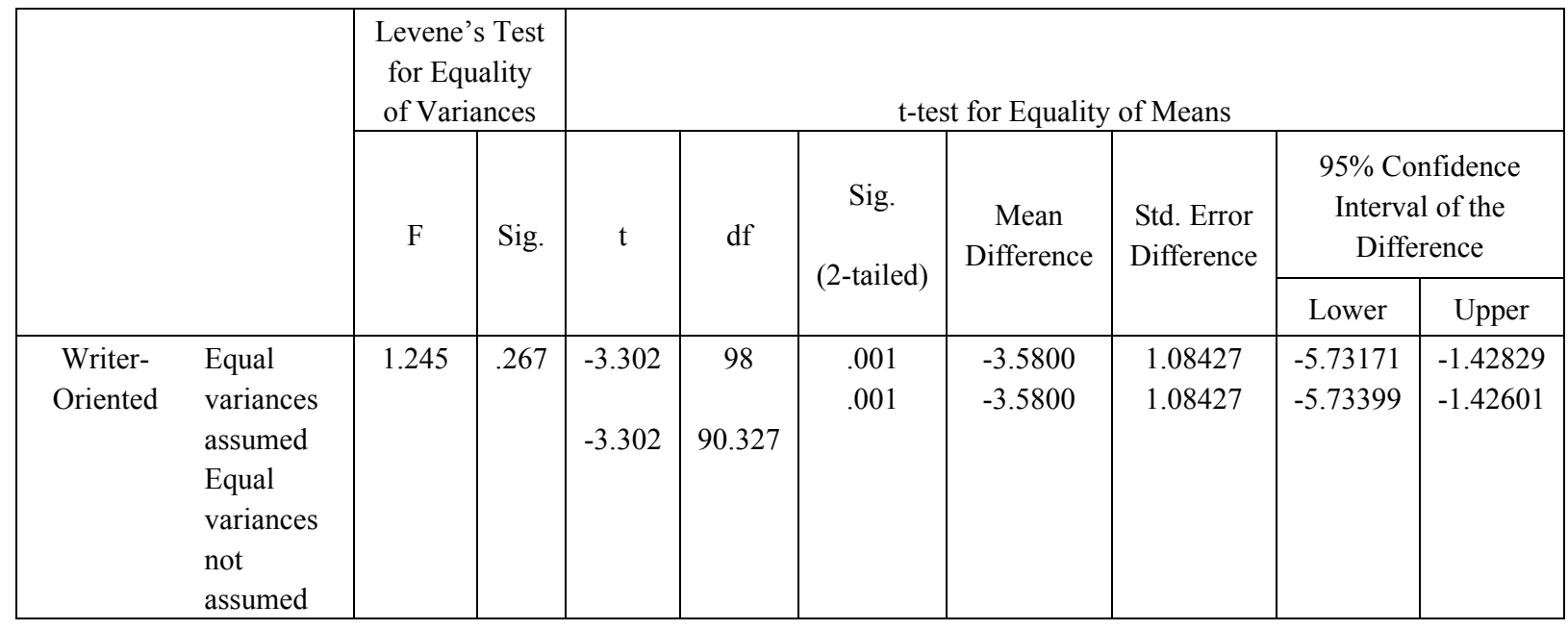


Table 12. Mean number of "reader-oriented" hedges in quantitative and qualitative articles

\begin{tabular}{|c|c|c|c|c|c|}
\hline \multirow{4}{*}{ Reader-Oriented } & & & & & Std. Error \\
& Article Genre & $\mathrm{N}$ & Mean & Std. Deviation & Mean \\
\cline { 2 - 7 } & Quantitative & 50 & 1.5600 & 2.20537 & .31189 .28 \\
& Qualitative & 50 & 3.2800 & 2.01058 & 434 \\
\hline
\end{tabular}

Table 13. Independent samples t-test analysis of "reader-oriented" hedges used in quantitative and qualitative articles

\begin{tabular}{|c|c|c|c|c|c|c|c|c|c|c|}
\hline & \multicolumn{2}{|c|}{$\begin{array}{c}\text { Levene's Test } \\
\text { for Equality of } \\
\text { Variances } \\
\end{array}$} & \multicolumn{7}{|c|}{ t-test for Equality of Means } \\
\hline & & \multirow[t]{2}{*}{$F$} & \multirow[t]{2}{*}{ Sig. } & \multirow[t]{2}{*}{$\mathrm{t}$} & \multirow[t]{2}{*}{$\mathrm{df}$} & \multirow[t]{2}{*}{$\begin{array}{c}\text { Sig. } \\
\text { (2-tailed) }\end{array}$} & \multirow[t]{2}{*}{$\begin{array}{c}\text { Mean } \\
\text { Difference }\end{array}$} & \multirow[t]{2}{*}{$\begin{array}{l}\text { Std. Error } \\
\text { Difference }\end{array}$} & \multicolumn{2}{|c|}{$\begin{array}{l}95 \% \text { Confidence } \\
\text { Interval of the } \\
\text { Difference }\end{array}$} \\
\hline & & & & & & & & & Lower & Upper \\
\hline $\begin{array}{l}\text { Reader- } \\
\text { Oriented }\end{array}$ & $\begin{array}{l}\text { Equal } \\
\text { variances } \\
\text { assumed } \\
\text { Equal } \\
\text { variances } \\
\text { not } \\
\text { assumed }\end{array}$ & .108 & .744 & $\begin{array}{l}-4.075 \\
-4.075\end{array}$ & $\begin{array}{c}98 \\
97.174\end{array}$ & $\begin{array}{l}.000 \\
.000\end{array}$ & $\begin{array}{l}-1.7200 \\
-1.7200\end{array}$ & $\begin{array}{l}.42205 \\
.42205\end{array}$ & $\begin{array}{l}-2.55754 \\
-2.55762\end{array}$ & $\begin{array}{l}-.88246 \\
-.88238\end{array}$ \\
\hline
\end{tabular}

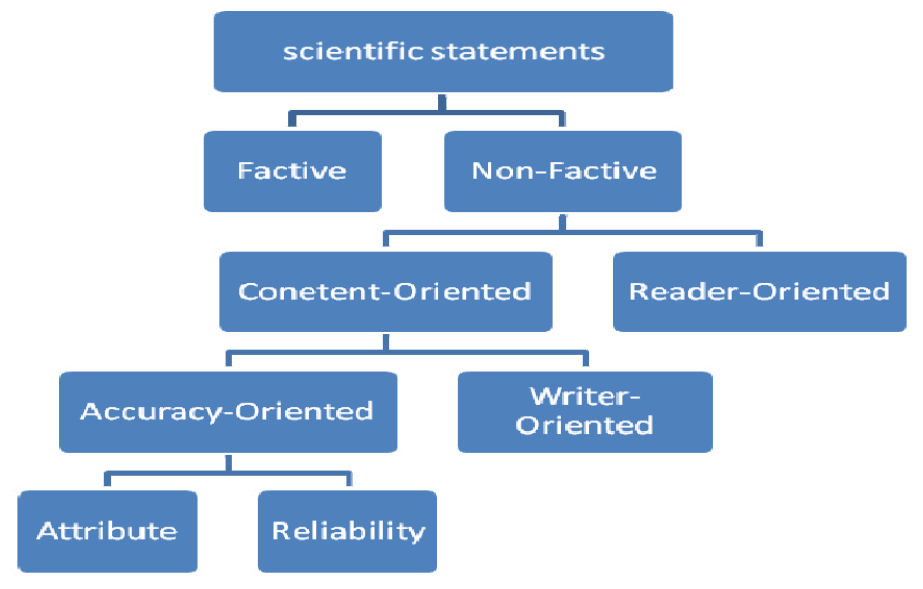

Figure 1. Hyland Model (1996) 


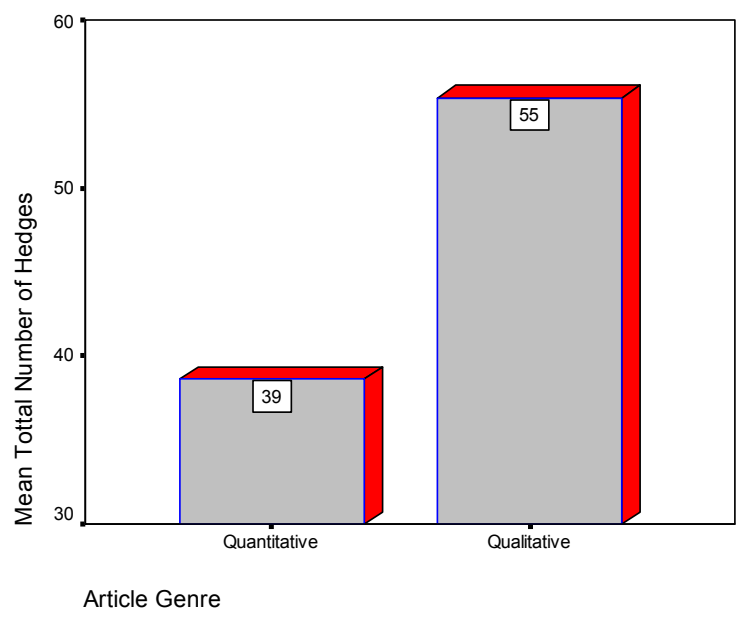

Figure 2. Mean number of hedge words used in quantitative and qualitative articles

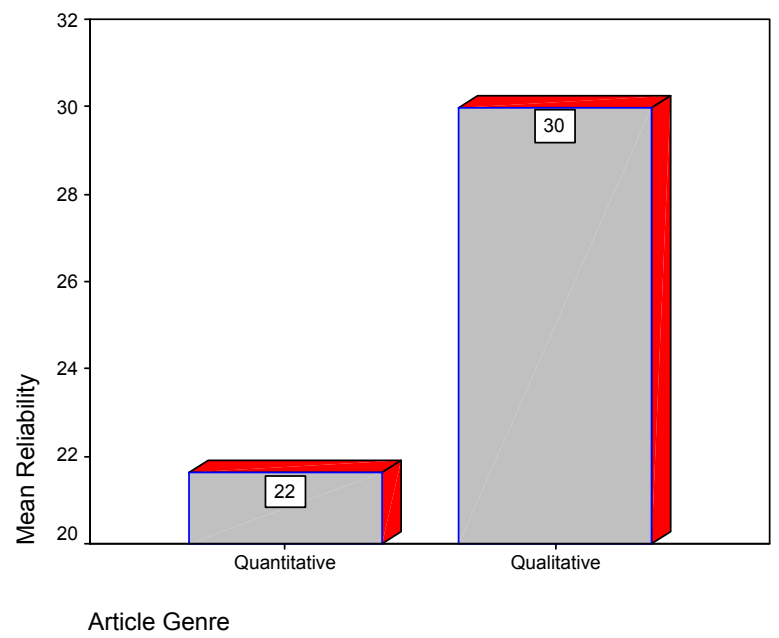

Figure 3. Mean number of "reliability" hedges in quantitative and qualitative articles

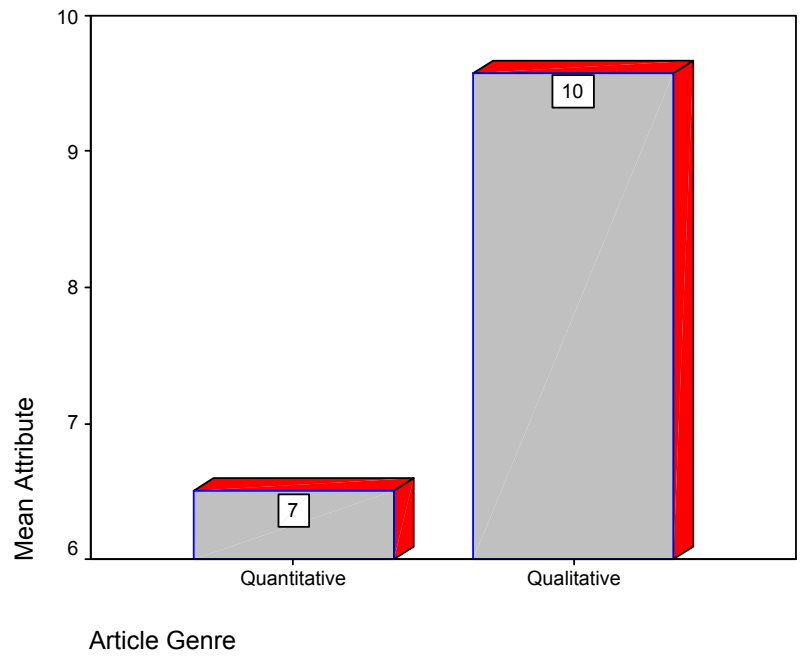

Figure 4. Mean number of "attribute" hedges in quantitative and qualitative articles 


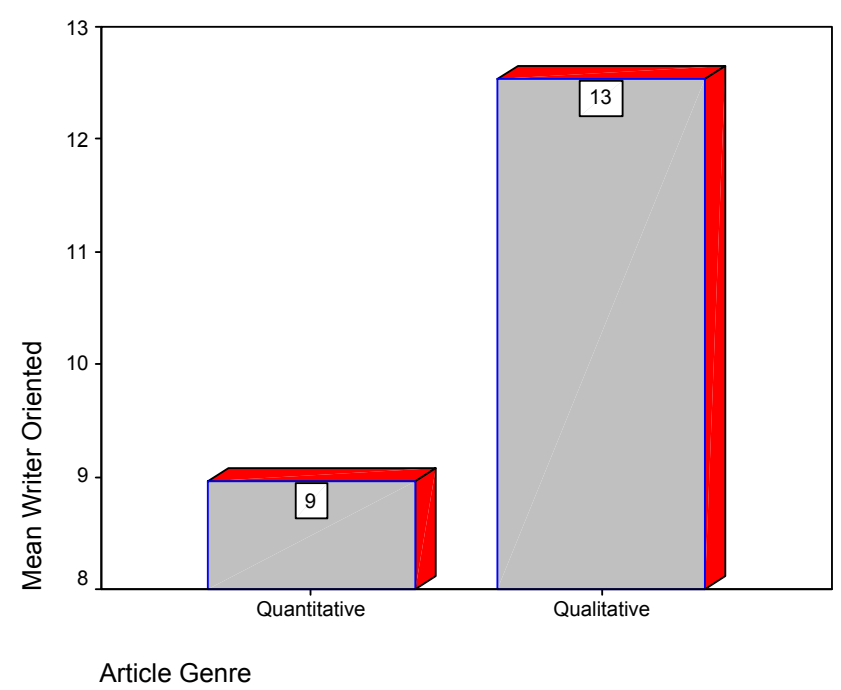

Figure 5. Mean number of "writer-oriented" hedges in quantitative and qualitative articles

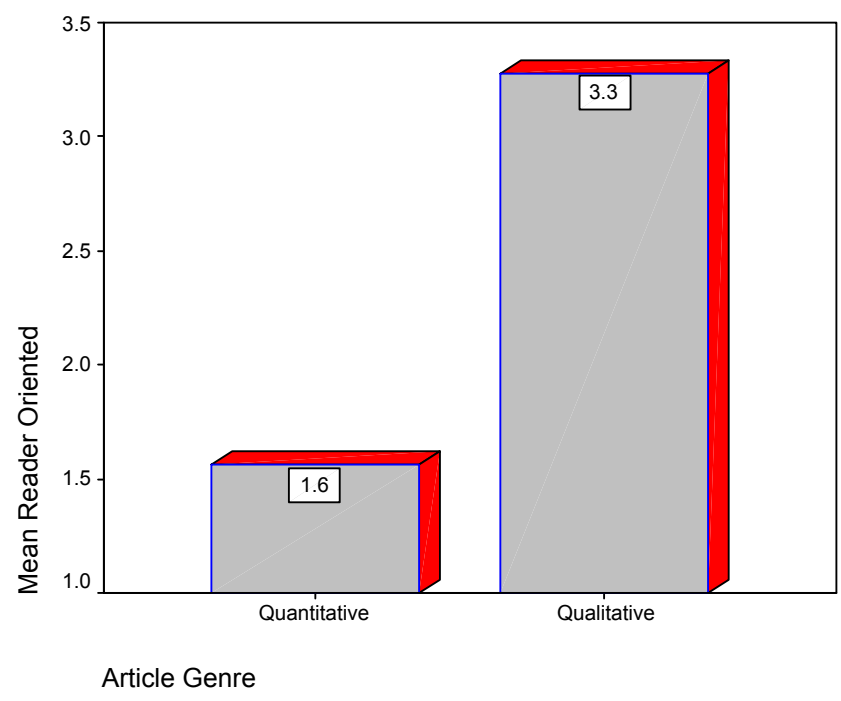

Figure 6. Mean number of "reader-oriented" hedges in quantitative and qualitative articles 